\title{
Influences on the Entrepreneurial Activities of Women Academics
}

\author{
Kaethe Schneider \\ Institute for Education and Culture, Chair of Adult Education, Friedrich-Schiller-University, Jena, Germany \\ Email: k.schneider@uni-jena.de
}

How to cite this paper: Schneider, K. (2022). Influences on the Entrepreneurial Activities of Women Academics. Psychology, 13, 78-88.

https://doi.org/10.4236/psych.2022.131006

Received: December 23, 2021

Accepted: January 21, 2022

Published: January 24, 2022

Copyright $\odot 2022$ by author(s) and Scientific Research Publishing Inc. This work is licensed under the Creative Commons Attribution International License (CC BY 4.0).

http://creativecommons.org/licenses/by/4.0/

\section{(c) (i) Open Access}

\begin{abstract}
There has been a sustained research activity in investigating academic entrepreneurship. Although women are less likely to be involved in entrepreneurship than men, the research investigating the entrepreneurship of academic women has received limited attention. This paper investigates the influences on the entrepreneurial activities of women academics by conducting a literature review. Individual and educational background factors, such as management education, human capital, as well as being in a senior faculty position affect the entrepreneurial propensity of female academics in a positive way, while age and institute directorships have a negative influence on entrepreneurship. However, equal gender distributions of professorship, of a selection of specific disciplines, such as engineering or physical science, and of previous business experience would contribute to closing the gender gap and would be a catalyst for women academics to become entrepreneurs. This paper fills the research gap on systematizing the research on factors that influence entrepreneurial activities of female academics.
\end{abstract}

\section{Keywords}

Entrepreneurial Career Choices, Academic Entrepreneurs, Female Academic Entrepreneurship, Individual Influences, Contextual Influences

\section{Introduction}

In the last decades, there has been an increasing interest in studying entrepreneurial behavior, e.g. (Krueger et al., 2000; Audet, 2004; Moriano et al., 2012). A reason for this interest can be seen in the huge contribution of entrepreneurship to economic and societal development, see (Grimaldi et al., 2011; Iffländer et al., 2018).

Although the academic entrepreneurial behavior was investigated in the stu- 
dies, e.g. (Clarysse et al., 2011; Dohse et al., 2021; Fritsch \& Krabel, 2012; Haeussler \& Colyvas, 2010; Goethner \& Wyrwick, 2020; Greven et al., 2020; Grimm \& Jaenicke, 2012, Kolb \& Wagner, 2015; Krabel \& Müller, 2009; Lehmann \& Stockinger, 2019; Perkmann et al., 2013; Piontek \& Wyrwich, 2017), there are only a few studies predicting the entrepreneurial behavior of female academics. The focus of explaining the entrepreneurial activities of women is critical and important, especially considering that men are more likely to be engaged in entrepreneurship than women, and women face more challenges in their entrepreneurial endeavours compared to men, e.g. (Lawton-Smith et al., 2017).

The overall purpose of this study is thus to investigate the influences on entrepreneurial activities of women academics based on a literature review.

\section{Literature Review}

The literature review is conducted in two steps: In the first step, we present an overview of the literature that relates to systematic literature reviews of studies explaining entrepreneurial activities of academics at universities. After an initial overview of the related work, we examine in the second step specific prior work on the influences on the entrepreneurial activities of women academics at universities.

Step 1: We found three systematic literature reviews explaining entrepreneurial activities of women academics.

A review undertaken of 66 studies published between 2007 and 2018 looking at the influences on academic entrepreneurship intentions of scientists has shown that three factors of influences emerge from the studies: individual, organizational and institutional variables (Neves \& Brito, 2020). Following the Theory of Planned Behavior (TPB) the intention is a predictor of the action (Ajzen, 1991). The individual variables, that exert a significant positive influence on the academic entrepreneurial intentions in all reviewed studies, are the following: a) Demographic background including gender and family background; b) The educational background with the academic status; c) The motivations including the expectations that academic engagement will enhance career success, the academic recognition expectations, the risk-taking propensity, the joy, the challenge, the curiosity, and the moral duty; d) The social capital including professional and personal networks; e) The human capital with the patenting experience and the entrepreneurial abilities (Neves \& Brito, 2020). For the influencing organizational variables, Neves \& Brito (2020) found in their review the quality of the university and the department quality. The influencing institutional-level factors include the research type of the scientific discipline (Neves \& Brito, 2020). In terms of the influential system, Neves \& Brito (2020) state, that the push factors are "multiple", "context dependent", "hierarchy dependent", "heterogeneous", "dependent on each other and against each other" which makes the system even more complex and dynamic. 
Grünhagen \& Volkmann (2014) refer to a systematization widely used in the university entrepreneurship literature: They suggest three levels of influence factors: university-wide organizational issues, department-level influences including the work environment of scientists within their faculty and finally personal influences at the level of the individual scientist. For the factors of the university organizations, the university administration attitudes, the encouragement from university, the university's active support and the intensity of industry collaboration exert an influence on scientists' entrepreneurial intentions (Grünhagen \& Volkmann, 2014). Regarding the department and work environment, the faculty peer approval, the peer entrepreneurial activity and the research group support seem to exert a positive influence on the entrepreneurial intentions (Grünhagen \& Volkmann, 2014). The individual influences of the scientists relate to the entrepreneurial self-identity, the degree of freedom at work, the opportunity costs of founding, the benefits of commercialization and prior entrepreneurial experience (Grünhagen \& Volkmann, 2014).

Following the systematic literature review conducted by Hossinger et al. (2020) for reviewed 193 articles published between 2000 and 2019, the influences of the academic spin-offs refer to micro-, meso- and macro-level factors. The micro-level factors address the influences of the individual, and include the following: 1) The intrinsic motivation (e.g. inner satisfaction, and self-realization); 2) The extrinsic motivation (e.g. grants, academic recognition, reputation and promotion); 3) Human capital (e.g. prior commercial and entrepreneurial experience, prior industrial work experience, business management experience, and domain-specific research experience); 4) Social capital (e.g. professional, personal and business social networks); 5) The psychological factors (e.g. attitudes, perceived behavioral control and social norms according to the theory of planned behavior, hybrid role identity with a focal academic self and a secondary commercial persona, the entrepreneurial self-efficacy (ESE), promotion focus for striving to achieve positive goals according to the regulatory focus theory); 6) Personality and demographic characteristics (e.g. extraversion, emotional stability, openness to experience, age, gender, career status and seniority); 7) Faculty quality, research types and disciplines (diverse and balanced skillsets, applied research, and science, engineering and physics disciplines (Hossinger et al., 2020)). The meso-level influencing factors of the organization of the university refer to the 1) University characteristics with the elements of applied research, prior industry cooperation experiences, solid resource bases, reputation and university prestige; 2) The entrepreneurial orientations including the entrepreneurial culture and climate within the university and the departments; 3) The support mechanisms with the university regulations, incubation services, financial support and entrepreneurship education (Hossinger et al., 2020). The macro-level factors consist of the social-economic environment, like the contextual factors (Hossinger et al., 2020). Drivers for the academic spin-offs at the macro-level are 1) For the regional context the level of economic development, cul- 
ture and histories, geographical location and the entrepreneurial environment; 2) For the national context the government instruments, regulations and the support programs (Hossinger et al., 2020).

In sum, the studies in this field relates to the predictors of academic entrepreneurship independently of gender. However, some studies can be found that include gender.

Step 2: We will present the single research studies grouped according to the following categories:

- Studies including gender as explanatory variable.

- Studies including separate regressions for females and males.

Studies including gender as explanatory variable (Table 1): Using data from a survey conducted in 2008-2009 with 22,556 UK academics, Abreu \& Grinevich (2017) found that among the personal characteristics of the respondents, such as gender, academic position, type of research, academic discipline (health sciences, biological sciences, engineering and physical sciences, social sciences, business and media, humanities, creative arts, or education), affiliation with Russell Group research-intensive university, business experience, network participant, perceived constraints and ethical/moral views of research commercialization, and academic entrepreneurship, gender exerts a marginal significant negative impact on the spinout activity of academics (Abreu \& Grinevich, 2017).

Based on a data base of 1693 high profile scientists receiving large-scale funding from the National Cancer Institute, Aldridge \& Audretsch (2011) found

Table 1. Impact of gender on academic entrepreneurship.

\begin{tabular}{|c|c|c|}
\hline Authors/Year & Sample & Impact \\
\hline Abreu \& Grinevich (2017) & UK academics (2008-2009) & $\begin{array}{l}\text { Negative: Spinout activity } \\
\text { (Gender: female) }\end{array}$ \\
\hline Aldridge \& Audretsch (2011) & $\begin{array}{l}\text { United States-based scientists awarded a research grant by the } \\
\text { National Cancer Institute between } 1998 \text { and } 2002 \text { to } \\
\text { commercialize their research. Of those research grant awards } \\
\text { the largest } 20 \%\end{array}$ & Non-significant \\
\hline Alshumaimri et al. (2012) & $\begin{array}{l}\text { Scientists selected randomly from three universities in Saudi } \\
\text { Arabia: King Abdulaziz University, King Fahad University and } \\
\text { King Saud University }\end{array}$ & Non-significant \\
\hline Bijedic et al. (2014) & Academic scientists in 73 German universities & Negative (Gender: female) \\
\hline $\begin{array}{l}\text { Dohse et al. (2021) } \\
\text { Krabel \& Müller (2009) }\end{array}$ & $\begin{array}{l}\text { Researchers at the Max Planck Society (MPS) at different career } \\
\text { stages in Germany }\end{array}$ & $\begin{array}{l}\text { Negative: Business Owner } \\
\text { (Gender: female) } \\
\text { Non-significant: Nascent } \\
\text { Entrepreneurs } \\
\text { Non-significant: Nascent } \\
\text { Entrepreneurs }\end{array}$ \\
\hline Goel et al. (2015) & $\begin{array}{l}\text { Researchers at the Max Planck Society (MPS) at different career } \\
\text { stages in Germany }\end{array}$ & $\begin{array}{l}\text { Negative: Academic business } \\
\text { start-ups (Gender: female) }\end{array}$ \\
\hline
\end{tabular}

Source: Own elaboration. 
that out of the variables of age, gender, human and social capital, institutional influences, financial resources, being male has no significant impact on the propensity for the scientist to become an entrepreneur (Aldridge \& Audretsch, 2011).

Alshumaimri et al. (2012) found for 288 scientists of three universities in Saudi Arabia that out of the variables of experience, gender, social capital, human capital, and university and other institutional policies encouraging commercialization activities, the coefficient on the dummy variable indicating gender is not statistically significant. This means that male scientists are not more likely to be nascent entrepreneurs (Alshumaimri et al., 2012).

With focus on the overall academic entrepreneurship at German universities, a study was conducted by Bijedic et al. (2014) including gender as an independent variable. Bijedic et al. (2014) studied the individual and structural influences on the entrepreneurial activities of scientists in German universities based on data of the Institut für Mittelstandsforschung (ifm) in Bonn, Germany (Bijedic et al., 2014). Bijedic et al. (2014) found that personal factors such as being male, middle-aged and being of non-German nationality with entrepreneurial parents or partner promote the entrepreneurial activities of scientists in German universities using data of 5992 academic scientists in 73 German universities.

Based on 2604 completed interviews out of a total sample population of 7808 researchers at the Max Planck Society (MPS) in Germany at different career stages, Dohse et al. (2021) found that out of the variables of age, and gender, academic discipline, industry interactions, patents, educational background, citizenship, being female has a significant negative impact on business ownership of researchers, while its impact on nascent entrepreneurs is non-significant (Krabel \& Müller, 2009).

The definition of nascent entrepreneurs is based on the classification of the Global Entrepreneurship Monitor:

Thus, scientists were classified as nascent entrepreneurs if they were engaged in any activity associated with starting a business on the day of the interview. These activities may include applying for public or private financing, seeking venture capital, writing a business plan, looking for office space, or forming the founding team (Krabel \& Mueller, 2009: p. 952).

"Business ownership, by contrast, indicates that a person has created a sustainable venture that is able to survive in the long run (Dohse et al., 2021: p. 5)."

Likewise, Goel et al. (2015) also run regressions for the wholesample of men and women. Based on survey data of 2004 interviews from a large public research organization, German institutes of the Max Planck Society (MPS), among the variables of age, and gender, academic discipline, industry interactions, industrial experience, patents, educational background, citizenship, commerciali- 
zation attitudes, perceptions about attractiveness of entrepreneurship, accessibility of research being female has a significant negative impact on academic business start-ups (Goel et al., 2015).

Studies including separate regressions for females and males: We give a tabular summary with the predictors of women's academic entrepreneurship (Table 2). Goel et al. (2015) conducted a study of this type for researchers at a nonprofit research organization to predict entrepreneurial propensity. Compared to the male researchers the female age has a slightly negative impact, and industrial experience has a positive effect on entrepreneurial activities of females (Goel et al., 2015). Perceiving an increased reputation from academic entrepreneurship increases the entrepreneurial probability of female and male academics (Goel et al., 2015). Patenting history significantly impacts male activities, while for females the influences are insignificant (Goel et al., 2015).

Regarding the organizational factors (Table 3 ) the institute directorship has a strong negative impact on the entrepreneurial propensity of females while it is positive for males (Goel et al., 2015).

Politis et al. (2014) studied, how institutional structures in and around university-based incubators are predictors of women becoming incubator entrepreneurs. University incubators as entities that are often funded by tax money have

Table 2. Individual and educational background effect by academic entrepreneurship of females.

Individual and Educational Background

\begin{tabular}{ll}
\hline Age & $\begin{array}{l}\text { Negative } \\
\text { Goel et al. (2015) }\end{array}$ \\
Perception of increased reputation & $\begin{array}{l}\text { Positive } \\
\text { from academic entrepreneurship }\end{array}$ \\
Gatenting history & Non-significant \\
& Goel et al. (2015) \\
Industrial experience & Positive \\
& Goel et al. (2015) \\
\hline
\end{tabular}

Source: Own elaboration.

Table 3. Organizational background effect by academic entrepreneurship of females.

\begin{tabular}{ll}
\hline \multicolumn{1}{c}{ University context } & \\
\hline Institute directorship & $\begin{array}{l}\text { Negative } \\
\text { Goel et al. (2015) }\end{array}$ \\
$\begin{array}{l}\text { Female faculty in } \\
\text { senior positions }\end{array}$ & $\begin{array}{l}\text { Positive effect on becoming incubator entrepreneurs } \\
\text { Size of university }\end{array}$ \\
& $\begin{array}{l}\text { Non-significant effect on becoming incubator entrepreneurs } \\
\text { Politis et al. (2014) }\end{array}$
\end{tabular}

Source: Own elaboration. 
the function to accelerate entrepreneurship through business support (Politis et al., 2014). Based on data of over 1400 venture projects in 19 Swedish incubators, the authors applied multi-level logistic regression analysis to examine 793 new venture incubators projects (Politis et al., 2014).

They found, that at the university level, a higher proportion of female faculty in senior positions increases the likelihood of a female-led incubator project (Politis et al., 2014).

As for the institutional factors (Table 4) and specifically the incubator-led projects, the presence of a female on the incubator's board of directors exerts a positive influence on becoming incubators entrepreneurs, while the incubator age has no significant impact (Politis et al., 2014). Neither the proportion of female led start-ups in the region nor the number of start-ups per 1000 inhabitants exerts an influence on becoming incubator entrepreneurs (Politis et al., 2014). That the females choose more often than men research areas closely linked to the public and not-for-profit sectors (Rosa \& Dawson, 2006), corresponds with the motives of female academic entrepreneurs. Following the explorative qualitative study conducted by Iffländer et al. (2018), female academics are driven by the ideals of creating services or products for the common good and making a social difference.

Table 4. Institutional background effect by academic entrepreneurship of females.

\begin{tabular}{ll}
\hline $\begin{array}{l}\text { Incubator } \\
\text { Leadership: the presence of a female on the } \\
\text { incubator's board of directors }\end{array}$ & $\begin{array}{l}\text { Positive effect on becoming incubator } \\
\text { entrepreneurs } \\
\text { Politis et al. (2014) } \\
\text { Non-significant on becoming incubator } \\
\text { entrepreneurs } \\
\text { Politis et al. (2014) }\end{array}$ \\
Incubator age & \\
\hline $\begin{array}{l}\text { Context } \\
\text { Proportion of female led start-ups in the }\end{array}$ & $\begin{array}{l}\text { Non-significant on becoming incubator } \\
\text { entrepreneurs } \\
\text { Politis et al. (2014) }\end{array}$ \\
Number of start-ups per 1000 inhabitants & $\begin{array}{l}\text { Non-significant on becoming incubator } \\
\text { entrepreneurs } \\
\text { Politis et al. (2014) }\end{array}$ \\
\hline
\end{tabular}

Source: Own elaboration.

\section{Results}

Summarizing the individual variables that explain academic entrepreneurship in general, we can categorize two types of individual factors 1) Socio-demographic factors, such as for example age and gender; 2) Psychographic factors, such as traits, attitudes, perceived action control, abilities and experience, e.g. (Dohse et al., 2021; Clarysse et al., 2011; Fritsch \& Krabel, 2012; Goethner et al., 2012; Grimm \& Jaenicke, 2012; Haeussler \& Colyvas, 2011; Krabel \& Müller, 2009; 
Lehmann \& Stockinger, 2019; Obschonka et al., 2012, Perkmann et al., 2013; Kolb \& Wagner, 2015). The organizational variables differ in terms of 1) Industrial collaboration of the university; 2) Peer effects; 3) Organizational support; (4) Commercialization experience of the university; 5) Organizational climate of the chair; 6) The excellence initiative reflecting the quality of a department resp. the university, e.g. (Dohse et al., 2021; Goethner \& Wyrwick, 2020; Greven et al., 2020; Lehman \& Stockinger, 2019; Perkmann et al., 2013). On institutional level, 1) The type of the discipline; 2) The entrepreneurial-related policy; 3) The population development influences the entrepreneurial activities of scientists, e.g. (Clarysse et al., 2011; Fritsch \& Krabel, 2012; Perkmann et al., 2013; Piontek \& Wynwich, 2017).

Regarding the results in terms of the impact of gender on academic entrepreneurship, the evidence is equivocal in terms of the impact of gender on academic entrepreneurship.

Summarizing these studies including separate regressions for men and women, we conclude that management education, human capital, as well as being in a senior faculty position have a positive impact on the entrepreneurial propensity of female academics, while age and institute directorships interact negatively with entrepreneurship.

Using a nonparametric decomposition analysis, Abreu \& Grinevich (2017) found that the majority of the statistically significant gender gap in spinout activity can be explained by differences in the values of the explanatory variables such as for example seniority, type of research, discipline, and experience. The attributes that are typical for male academics and promote spinout activities characterize a minority of female academics.

The Blinder-Oaxaca decomposition shows that $61 \%$ of this gap can be explained by differences in the endowments, meaning that if female academics had the average attributes of the male academics in the sample, the gender gap would close by this amount (Abreu \& Grinevich, 2017: p. 780).

In addition to this component, the differences in the behavioral responses of female academics to those attributes explain the gender gap. This "unexplained component" might be interpreted in part as the gender-based discrimination and represents "the degree to which the gap would close if the female academics in the sample had the coefficients of the male academics (Abreu \& Grinevich, 2017: p. 780).” Abreu \& Grinevich (2017) demonstrated the gender gap in academic entrepreneurship, meaning, that both the values of the explanatory variables and the effects of those variables on academic entrepreneurship are different between female and male academics and these results have been affected by selection bias (Abreu \& Grinevich, 2017). Referring to the decomposition for individual variables, the values of the explanatory variables that explain the greatest proportions of the gender gap are "whether the individual is a professor (14\%), academic discipline, particularly engineering and the physical sciences (14\%), and whether the individual has previous experience in starting or run- 
ning a small business (23\%) (Abreu \& Grinevich, 2017: p. 780).” The authors conclude, for example in case of professorship, that, if the probability for the female and male average academic to become professor was the same, the gap would close by 14\% (Abreu \& Grinevich, 2017). The huge effect of the previous business experience shows that the missing one is a huge barrier for entrepreneurial activities (Abreu \& Grinevich, 2017).

\section{Discussion}

With this study, we contribute to systematizing the knowledge of the research of influencing factors of entrepreneurial activities of women academics.

While the results of the impact of gender on entrepreneurial activities of academics are ambiguous, the individual and educational background factors, such as management education, human capital, as well as being in a senior faculty position affect the entrepreneurial propensity of female academics in a positive way. Age and institute directorships, however, have a negative influence on entrepreneurship.

A more equal gender distribution of professorship, selection of specific disciplines, such as engineering or physical science, and of previous business experience would be a catalyst for women academics to become entrepreneurs.

If the probability for the female and male average academic to become professor, to select specific disciplines, such as engineering, and to make business experience was the same, the gap would close substantially. Thus, promoting gender equality in the mentioned conditions of academia would have a huge consequential effect on closing the entrepreneurial gender gap.

\section{Conflicts of Interest}

The author declares no conflicts of interest regarding the publication of this paper.

\section{References}

Abreu, M., \& Grinevich, V. (2017). Gender Patterns in Academic Entrepreneurship. The Journal of Technology Transfer, 42, 763-794. https://doi.org/10.1007/s10961-016-9543-y

Ajzen, I. (1991). The Theory of Planned Behavior. Organizational Behavior and Human Decision Processes, 50, 179-211. https://doi.org/10.1016/0749-597890020-t

Aldridge, T. T., \& Audretsch, D. (2011). The Bayh-Dole Act and Scientist Entrepreneurship. Research Policy, 40, 1058-1067. https://doi.org/10.1016/j.respol.2011.04.006

Alshumaimri, A., Aldridge, T., \& Audretsch, D. B. (2012). Scientist Entrepreneurship in Saudi Arabia. The Journal of Technology Transfer, 37, 648-657.

https://doi.org/10.1007/s10961-011-9230-y

Audet, J. (2004). A Longitudinal Study of the Entrepreneurial Intentions of University Students. Academy of Entrepreneurship Journal, 10, 3-16.

Bijedic, T., Maaß, F., Schröder, C., \& Werner, A. (2014). Der Einfluss institutioneller Rahmenbedingungen auf die Gründungsneigung von Wissenschaftlern an deutschen 
Hochschulen (IfM-Materialien Nr. 233). Institut für Mittelstandsforschung Bonn.

Clarysse, B., Bruneel, J., \& Wright, M. (2011). Explaining Growth Paths of Young Technology-Based Firms: Structuring Resource Portfolios in Different Competitive Environments. Strategic Entrepreneurship Journal, 5, 137-157. https://doi.org/10.1002/sej.111

Dohse, D., Goel, R. K., \& Göktepe-Hultén, D. (2021). Paths Academic Scientists Take to Entrepreneurship: Disaggregating Direct and Indirect Influences. Managerial and Decision Economics, 42, 1740-1753. https://doi.org/10.1002/mde.3341

Fritsch, M., \& Krabel, S. (2012). Ready to Leave the Ivory Tower: Academic Scientists' Appeal to Work in the Private Sector. The Journal of Technology Transfer, 37, 271-296. https://doi.org/10.1007/s10961-010-9174-7

Goel, R. K., Göktepe-Hultén, D., \& Ram, R. (2015). Academics’ Entrepreneurship Propensities and Gender Differences. The Journal of Technology Transfer, 40, 161-177. https://doi.org/10.1007/s10961-014-9372-9

Goethner, M., \& Wyrwich, M. (2020). Cross-Faculty Proximity and Academic Entrepreneurship: The Role of Business Schools. The Journal of Technology Transfer, 45, 10161062. https://doi.org/10.1007/s10961-019-09725-0

Goethner, M., Obschonka, M., Silbereisen, R. K. \& Cantner, U. (2012). Scientists' Transition to Academic Entrepreneurship: Economic and Psychological Determinants. Journal of Economic Psychology, 33, 628-641. https://doi.org/10.1016/j.joep.2011.12.002

Greven, A., Strese, S., \& Brettel, M. (2020). Determining Scientists' Academic Engagement: Perceptions of Academic Chairs' Entrepreneurial Orientation and Network Capabilities. The Journal of Technology Transfer, 45, 1376-1404. https://doi.org/10.1007/s10961-019-09750-z

Grimaldi, R., Kenney, M., Siegel, D. S., \& Wright, M. (2011). 30 Years after Bayh-Dole: Reassessing Academic Entrepreneurship. Research Policy, 40, 1045-1057. https://doi.org/10.1016/j.respol.2011.04.005

Grimm, H. M., \& Jaenicke, J. (2012). What Drives Patenting and Commerzialisation Activity at East German Universities? The Role of New Public Policy, Institutional Environment and Individual Prior Knowledge. The Journal of Technology Transfer, 37, 454-477. https://doi.org/10.1007/s10961-010-9195-2

Grünhagen, M., \& Volkmann, C. K. (2014). Antecedents of Academics' Entrepreneurial Intentions-Developing a People-Oriented Model for University Entrepreneurship. International Journal of Entrepreneurial Venturing, 6, 179-200. https://doi.org/10.1504/ijev.2014.062751

Haeussler, C., \& Colyvas, J. A. (2011). Breaking the Ivory Tower: Academic Entrepreneurship in the Life Sciences in UK and Germany. Research Policy, 40, 41-54. https://doi.org/10.1016/j.respol.2010.09.012

Hossinger, S. M., Chen, X., \& Werner, A. (2020). Drivers, Barriers and Success Factors of Academic Spin-Offs: A Systematic Literature Review. Management Review Quarterly, 70, 97-134. https://doi.org/10.1007/s11301-019-00161-w

Iffländer, V., Sinell, A., \& Schraudner, M. (2018). Does Gender Make a Difference? Gender Differences in the Motivations and Strategies of Female and Male Academic Entrepreneurs. In S. Birkner, K. Ettl, F. Welter, \& I. Ebbers (Eds.), Women's Entrepreneurship in Europe (pp. 65-82). Springer. https://doi.org/10.1007/978-3-319-96373-0_4

Kolb, C., \& Wagner, M. (2015). Crowding in or Crowding out: the Link between Academic Entrepreneurship and Entrepreneurial Traits. The Journal of Technology Transfer, 40, 387-408. https://doi.org/10.1007/s10961-014-9346-y 
Krabel, S., \& Mueller, P. (2009). What Drives Scientists to Start Their Own Company? Research Policy, 38, 947-956. https://doi.org/10.1016/j.respol.2009.02.005

Krueger, N. F., Reilly, M. D., \& Carsrud, A. L. (2000). Competing Models of Entrepreneurial Intentions. Journal of Business Venturing, 15, 411-432.

https://doi.org/10.1016/s0883-902600033-0

Lawton-Smith, H., Etzkowitz, H., Meschitti, V., \& Poulovassilis, A. (2017). Female Academic Entrepreneurship: Reviewing the Evidence and Identifying the Challenges. In C. Henry, T. Nelson, \& K. Lewis (Eds.), The Routledge Companion to Global Female Entrepreneurship (pp. 78-92). Routledge.

Lehmann, E. E., \& Stockinger, S. A. E. (2019). Entrepreneurship in Higher Education: The Impact of Competition-Based Policy Programmes Exemplified by the German Excellence Initiative. Higher Education Quarterly, 73, 70-84.

https://doi.org/10.1111/hequ.12188

Moriano, J. A., Gorgievski, M., Laguna, M., Stephan, U., \& Zarafshani, K. (2012). A CrossCultural Approach to Understanding Entrepreneurial Intention. Journal of Career Development, 39, 162-185. https://doi.org/10.1177/0894845310384481

Neves, S., \& Brito, C. (2020). Academic Entrepreneurship Intentions: A Systematic Literature Review. Journal of Management Development, 39, 645-704.

https://doi.org/10.1108/jmd-11-2019-0451

Obschonka, M., Goethner, M., Silbereisen, R. K., \& Cantner, U. (2012). Social Identity and the Transition to Entrepreneurship: The Role of Group Identification with Workplace Peers. Journal of Vocational Behavior, 80, 137-147.

https://doi.org/10.1016/j.jvb.2011.05.007

Perkmann, M., Tartari, V., McKelvey, M., Autio, E., Broström, A., D’Este, P. et al. (2013). Academic Engagement and Commercialisation: A Review of the Literature on University-Industry Relations. Research Policy, 42, 423-442.

https://doi.org/10.1016/j.respol.2012.09.007

Piontek, M., \& Wyrwich, M. (2017). The Emergence of Entrepreneurial Ideas at Universities in Times of Demographic Change: Evidence from Germany. Review of Regional Research, 37, 1-37. https://doi.org/10.1007/s10037-016-0111-6

Politis, D., Gabrielsson, J., \& Lindholm Dahlstrand, Å. (2014). Academic Entrepreneurship: Multi-Level Factors Associated with Female-Led Incubator Projects. In K. Lewis, C. Henry, E. J. Gatewood, \& J. Watson (Eds.), Women's Entrepreneurship in the 21st Century: An International Multi-Level Research Analysis (1st ed., pp. 32-49). Edward Elgar Publishing. https://doi.org/10.4337/9781782544616.00009

Rosa, P., \& Dawson, A. (2006). Gender and the Commercialization of University Science: Academic Founders of Spinout Companies. Entrepreneurship \& Regional Development, 18, 341-366. https://doi.org/10.1080/08985620600680059 